\title{
Current Clinical Indications for Small Bowel Capsule Endoscopy
}

\author{
Indicações Clínicas Actuais para Enteroscopia por Cápsula
}

\author{
Bruno ROSA $\bowtie 1$, José COTTER ${ }^{1,2,3}$ \\ Acta Med Port 2015 Sep-Oct;28(5):632-639
}

ABSTRACT

Introduction: Small bowel capsule endoscopy is currently the first line diagnostic examination for many diseases affecting the small bowel. This article aims to review and critically address the current indications of small bowel capsule endoscopy in clinical practice.

Material and Methods: Bibliographic review of relevant and recent papers indexed in PubMed.

Results and Discussion: Small bowel capsule endoscopy enables a non-invasive full-assessment of the small bowel mucosa, with high diagnostic yield even for subtle lesions. In patients with obscure gastrointestinal bleeding, diagnostic yield is higher when performed early after the onset of bleeding. Endoscopic treatment of angioectasias using balloon-assisted enteroscopy may contribute to reduce rebleeding, while the risk of rebleeding in patients with "negative" small bowel capsule endoscopy is debatable. Cross-sectional imaging may be more accurate than small bowel capsule endoscopy for the diagnosis of large small bowel tumors. The Smooth Protruding Index on Capsule Endoscopy (SPICE score) may help to differentiate submucosal tumors from innocent bulges. Small bowel capsule endoscopy is also a key diagnostic instrument in patients with suspected Crohn's disease and non-diagnostic ileocolonoscopy; it may also influence prognosis and therapeutic management, by determining disease extent and activity in patients with known Crohn's disease. The role of small bowel capsule endoscopy to investigate possible complications in patients with non-responsive coeliac disease is evolving.

Conclusions: Small bowel capsule endoscopy is a valuable diagnostic instrument for patients with obscure gastrointestinal bleeding and/or suspected small bowel tumors; it may also be a key examination in patients with suspected Crohn's disease, or patients with known Crohn's disease to fully assess disease extension and activity; finally, it may contribute for the diagnosis of complications of non-responsive coeliac disease.

Keywords: Capsule Endoscopy; Intestinal Diseases.

\section{RESUMO}

Introdução: A enteroscopia por cápsula é o exame de primeira linha no diagnóstico de diversas patologias do intestino delgado. Este artigo tem por objectivo rever e analisar criticamente as indicações actuais para enteroscopia por cápsula na prática clínica.

Material e Métodos: Revisão bibliográfica suportada em artigos indexados na PubMed.

Resultados e Discussão: A enteroscopia por cápsula permite a avaliação não invasiva da mucosa do intestino delgado, com elevado rendimento diagnóstico. Em doentes com hemorragia digestiva de causa obscura, o rendimento da enteroscopia por cápsula aumenta quando realizada precocemente após o evento hemorrágico. O tratamento das angiectasias com enteroscopia assistida por balão permite diminuir a recidiva hemorrágica, enquanto o risco de recidiva em doentes com enteroscopia por cápsula "negativa" é controverso. A entero-TC/entero-RM podem superiorizar-se à enteroscopia por cápsula no diagnóstico de alguns tumores. O 'Smooth Protruding Index on Capsule Endoscopy' (score SPICE) auxilia na diferenciação entre verdadeiros tumores submucosos e abaulamentos não patológicos. A enteroscopia por cápsula é valiosa em doentes com suspeita de doença de Crohn quando a ileocolonoscopia não é diagnóstica, permitindo também estadiar a extensão e actividade das lesões em doentes com diagnóstico prévio de doença de Crohn, com potenciais implicações prognósticas e terapêuticas. A enteroscopia por cápsula permite ainda o diagnóstico de complicações em doentes com doença celíaca refractária.

Conclusões: Actualmente, a importância da enteroscopia por cápsula é reconhecida no contexto da hemorragia digestiva de causa obscura e/ou suspeita de tumores do intestino delgado, bem como na suspeita de doença de Crohn ou em doentes com doença de Crohn conhecida para determinar a localização, extensão e actividade da doença, e ainda para a investigação de doentes com doença celíaca refractária.

Palavras-chave: Doenças Intestinais; Endoscopia por Cápsula.

\section{INTRODUCTION}

Small bowel capsule endoscopy (SBCE) has assumed a central role in the investigation of many diseases affecting the small bowel. It enables a non-invasive evaluation of the entire lenght of the small bowel, providing the highest diagnostic yield among all of currently available noninvasive diagnostic modalities. ${ }^{1}$ The European Society of Gastrointestinal Endoscopy (ESGE) has recently endorsed

a comprehensive guide for the clinical application of enteroscopy. ${ }^{2}$ The main indications for SBCE are obscure gastrointestinal bleeding (OGIB) and suspected or known Crohn's disease (CD), followed by other less frequent clinical indications such as suspected small bowel tumors, surveillance of polyposis syndromes and coeliac disease.

1. Gastroenterology Department. Centro Hospitalar do Alto Ave. Guimarães. Portugal.

2. Life and Health Sciences Research Institute. School of Health Sciences. Universidade do Minho. Braga. Portugal.

3. Life and Health Sciences Research Institute/3B's. PT Government Associate Laboratory. Braga/Guimarães. Portugal.

$\triangle$ Autor correspondente: Bruno Rosa. brunorosa@chaa.min-saude.pt

Recebido: 26 de Dezembro de 2014 - Aceite: 19 de Maio de 2015 | Copyright @ Ordem dos Médicos 2015 


\section{MATERIAL AND METHODS}

This review article was based on a critical analysis of the most relevant and/or recent papers indexed in the PubMed regarding clinical applications of SBCE.

\section{RESULTS AND DISCUSSION \\ Obscure gastrointestinal bleeding}

Obscure gastrointestinal bleeding (OGIB) is defined as bleeding from the gastrointestinal tract that remains undiagnosed after esophagogastroduodenoscopy (EGD) and colonoscopy, generally corresponding to midgastrointestinal bleeding, i.e., the origin of bleeding being located in the small bowel between the ampulla of Vater and the ileocecal valve. ${ }^{3}$ Clinically, OGIB may present in the form of occult (positive fecal occult blood test and/or irondeficiency anemia) or overt bleeding (passage of visible blood, usually as melena or hematochezia). It accounts for approximately $5 \%$ of all gastrointestinal haemorrhage and up to $30 \%$ of all cases of iron-deficiency anemia, ${ }^{4}$ although in up to $25 \%$ of the cases, the origin of bleeding may in fact be related to missed or recently healed lesions within the reach of EGD or colonoscopy. A systematic review including over 20.000 patients reported OGIB as the most common indication for SBCE, accounting for almost two thirds of cases. ${ }^{5}$ In that large review, the most common lesions responsible for bleeding were angioectasias (Fig. 1), accounting for approximately half of the cases, ${ }^{5}$ while ulcers and inflammatory lesions, often related to nonsteroidal anti-inflammatory drugs (NSAIDs) or Crohn's disease, accounted for $26.8 \%$ of cases, $8.8 \%$ of patients had small bowel neoplastic lesions and $7.7 \%$ had other less common type of lesions responsible for the OGIB.

\section{Diagnostic yield of SBCE}

In a meta-analysis by Triester et al, ${ }^{1}$ the diagnostic yield

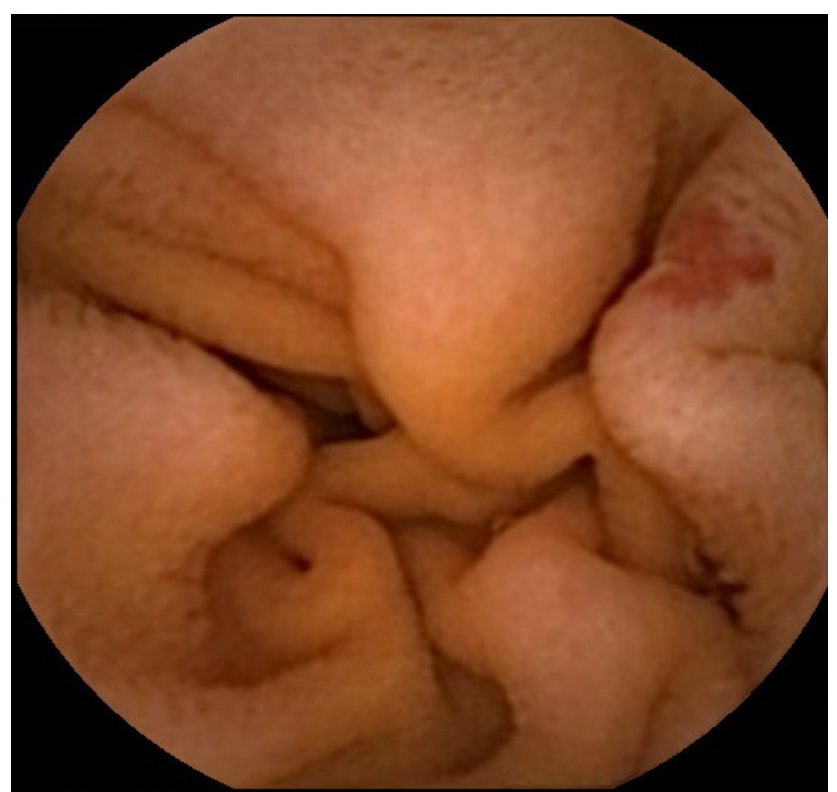

Figure 1 - Small bowel angioectasia in a patient with iron-deficiency anemia of SBCE was superior to push enteroscopy [incremental yield $(I Y)=30 \%$, small bowel follow-through (IY $=36 \%$ ), CT enteroclysis (IY $=38 \%$ ) and MRI (IY $=36 \%$ ) in patients with OGIB. Marmo et $\mathrm{al}^{6}$ reported an absolute pooled difference in the rate of positive findings of SBCE versus alternative modalities of $41 \%(95 \% \mathrm{Cl}: 35.6 \%-45.9 \%)$. The diagnostic yield of SBCE is similar to double-balloon (DBE) providing that both oral and anal insertion route are performed. ${ }^{7}$ In routine clinical practice, SBCE is usually the initial test because of its non-invasiveness, ability to view the entire small bowel, and guidance of the initial route of balloon-assisted enteroscopy (BAE), in those cases where patients with positive findings on SBCE will require biopsies or therapeutic intervention. ${ }^{8}$ Koulaouzidis et al ${ }^{9}$ reported a pooled diagnostic yield of $66.6 \%$ (95\% Cl: $61.0 \%-72.3 \%$ ) in patients with iron-deficiency anemia submitted to SBCE.

\section{Acute overt OGIB}

In patients with overt bleeding, the diagnostic yield of SBCE is higher if performed early after its onset. Pennazio et al ${ }^{10}$ reported a significantly higher diagnostic yield in patients with ongoing overt OGIB $(92.3 \%)$ versus occult OGIB $(44.2 \%)$ or previous history of overt OGIB $(12.9 \%)$. Bresci et al ${ }^{11}$ reported a diagnostic yield of $92 \%$ when SBCE was performed within the first two weeks after the diagnosis of OGIB, versus $34 \%$ when it was performed later than the second week. Lecleire et al ${ }^{12}$ followed a cohort of patients with severe overt OGIB, with negative upper and lower endoscopies performed within $72 \mathrm{~h}$ after admission, and urgent SBCE performed within the subsequent $48 \mathrm{~h}$. Fresh blood was seen in $75 \%$ and relevant lesions were detected in $67 \%$ of patients, leading to further endoscopic $(54 \%)$, surgical $(22 \%)$, or radiological $(2 \%)$ procedures. In another recent study of 144 patients with overt OGIB, SBCE resulted in higher detection rate of active bleeding and/or angioectasias $(44.4 \%$ vs $27.8 \%, p=0.046)$ when performed within $72 \mathrm{~h}$ of hospital admission. ${ }^{13}$ In a randomized controlled trial, Leung et $\mathrm{a}^{14}$ found that the diagnostic yield of SBCE was higher than angiography ( $53.3 \%$ vs $20 \% ; p=0.016$ ) in patients with severe overt OGIB, and the cumulative risk of rebleeding was $16.7 \%$ and $33.3 \%$, respectively $(p=0.10)$. The use of BAE as the first line examination in this setting has been advocated as a cost-effective approach, due to the high probability of positive findings and the possibility of immediate therapeutic intervention. ${ }^{15}$ However, SBCE may still prove useful in those cases, by indicating the optimal route of insertion and by diagnosing possible synchronous lesions.

\section{Rebleeding}

Patients with multiple small bowel angioectasias seem to be at the highest risk of bleeding during the follow-up after SBCE. ${ }^{16}$ Some authors reported a significant decrease in the risk of rebleeding after SBCE-guided therapeutic interventions. ${ }^{17}$ In a recent prospective multicenter study, ${ }^{18}$ the rate of rebleeding at twelve months among patients with small bowel vascular lesions detected by SBCE and 
subsequently treated with DBE was $35 \%$; multivariate analysis indicated that cardiac disease (HR 2.04, 95 $\% \mathrm{Cl}: 1.20-3.48 ; p<0.01)$ and the presence of overt bleeding (HR 1.78, 95\% Cl: $1.07-2.97 ; p=0.03$ ) were independently associated with the risk of rebleeding. The negative predictive value of a 'negative' SBCE in patients with OGIB is currently debatable. Lai et al ${ }^{19}$ reported a long term rebleeding rate of $5.6 \%$ in patients with OGIB and 'negative' SBCE, versus $48.4 \%$ in patients with 'positive' findings, $p=0.003$. Similarly, Macdonald et $\mathrm{al}^{20}$ described that a 'negative' SBCE predicts low rebleeding rates $(11 \%$ versus $42 \%, p<0.05)$. Interestingly, in this study none of the patients with 'occult' OGIB and 'negative' SBCE experienced rebleeding. However, other authors have reported higher rates of up to $25 \%$ of patients with OGIB and negative SBCE experiencing rebleeding, ${ }^{21,22}$ the vast majority within the first two years of follow-up. The overall miss rate for SBCE has been estimated at $10 \%-30 \%$, and solitary lesions are more likely to be missed. ${ }^{23}$ These different outcomes may reflect distinct inclusion criteria, baseline clinical characteristics or duration of follow-up, as well as differences in inclusion criteria, particularly the case of $\mathrm{P} 1$ lesions, such as small erosions or red spots, which have uncertain bleeding potential according to the classification of Saurin et al, ${ }^{24}$ while $\mathrm{P} 2$ lesions (angioectasias, ulcers, tumors or varices) have a well recognized bleeding risk. Imagawa et al demonstrated improved visibility and detectability ${ }^{25}$ of small bowel lesions when using flexible spectral imaging color enhancement (FICE); hence, it could be a reasonable approach to review all 'negative' SBCE using the FICE mode before proceeding to further diagnostic investigations. ${ }^{26}$

\section{Small bowel tumors and polyposis syndromes}

The most common clinical presentation of small bowel tumors is obscure $\mathrm{Gl}$ bleeding (OGIB). ${ }^{27}$ The prevalence of small bowel tumors in patients with OGIB has been reported to range between $5 \%$ and $10 \%,{ }^{28,29}$ malignant tumors accounting for $60 \%$ to $75 \%$ of cases. ${ }^{27}$ In a large multicenter study, ${ }^{29}$ the main primary small bowel tumor type was gastrointestinal stromal tumor (GIST) (32\%), followed by adenocarcinoma (20\%) and carcinoid tumor (15\%) (Fig. 2); two thirds of metastatic tumors in the small bowel corresponded to melanomas. Up to $70 \%$ of the tumors detected by SBCE have been missed by previous imaging studies, particularly when smaller than $10 \mathrm{~mm} .{ }^{28}$ However, SBCE also has limitations and even large, protruding masses can be overlooked or seen only tangentially on one limited frame of the video. ${ }^{30}$ Moreover, SBCE is often unable to distinguish benign from malignant tumors, or even neoplastic from non-neoplastic lesions ${ }^{31}$. In a pooled analysis of 24 prospective studies $(n=530$ patients), the failure rate of SBCE in detecting small bowel tumors was reported at $18.9 \% .^{32}$ SBCE can miss single mass lesions because of limited field of vision, poor bowel preparation, rapid transit especially in the proximal small bowel (duodenum and proximal jejunum), folds and loop angulations hiding masses, lack of insufflation, non- continuous image capture or incomplete examination. ${ }^{30}$ Thus, patients should be further investigated after a nondiagnostic SBCE if there is a high suspicion of small bowel tumor. Cross-sectional imaging techniques such as CT or MR enterography allow for the detection of hypervascular small bowel masses, enable extraluminal assessment and identify possible metastatic lesions for staging purposes. Nonetheless, in clinical practice, the tumor is often diagnosed by SBCE in the first place, in patients being investigated for OGIB; subsequently, patients will often undergo crosssectional imaging for staging and eventually proceed to BAE to obtain biopsies for histopathologic diagnosis; BAE may also be used to remove retained capsules proximal to the tumor, as the risk of capsule retention has been reported to be high in this population, ranging from $1.4 \%$ to $17 \% .{ }^{27}$ From a practical point of view, if there is a suspicion of small bowel tumor based on previous cross-sectional imaging studies, BAE could be preferred over SBCE, in order to avoid the risk of capsule retention and to allow biopsies for histopathologic diagnosis. The diagnostic yield of DBE has been shown to be similar to the combination of CTE and SBCE, ${ }^{33}$ and the specificity is higher, mainly due to the high rate of false positive submucosal masses detected by SBCE. ${ }^{34}$

\section{Differentiating a submucosal tumoral lesion from an innocent bulge on SBCE}

Up to half of small bowel malignancies found by SBCE correspond to GIST or neuroendocrine tumors, endoscopically appearing as smooth, round, protruding lesions. ${ }^{29,35}$ Those lesions may be difficult to distinguish from 'innocent' bulges that result from bowel angulation or the impression of an adjacent loop, particularly if some features suggestive of tumoral lesions are absent, such as bleeding, ulceration or irregular surface. ${ }^{31}$ The prevalence of smooth, round protrusions at SBCE has been estimated

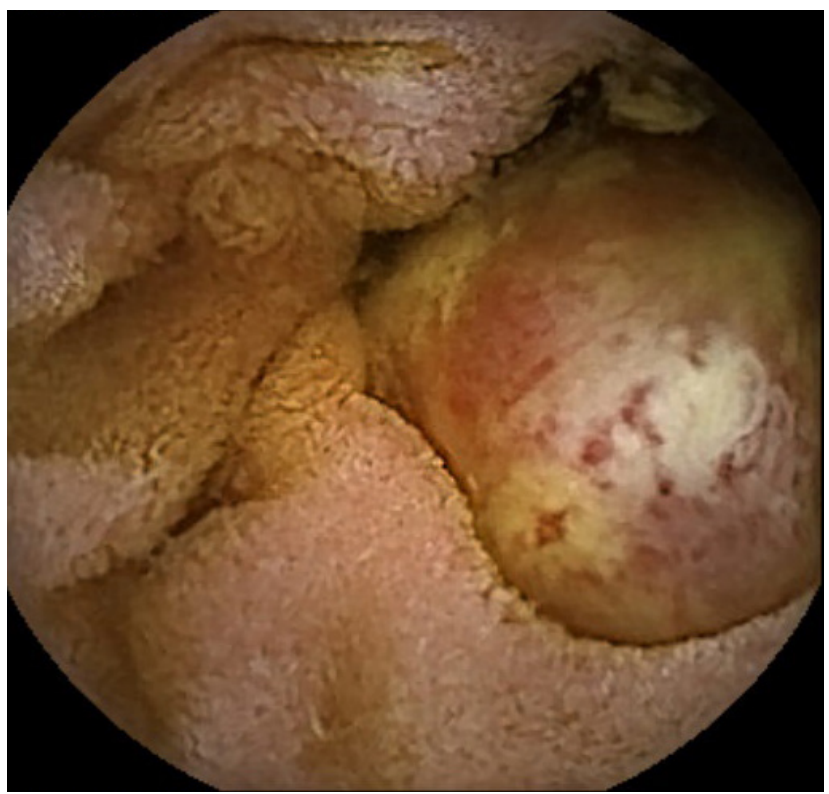

Figure 2 - Small bowel tumor 
at $5.8 \%$, but only approximately $25 \%$ of those correspond to submucosal tumors. ${ }^{35}$ The Smooth Protruding Index on Capsule Endoscopy (SPICE score) ${ }^{35}$ may be helpful to discriminate a bulge from a true mass on SBCE.

\section{Polyposis syndromes}

The recently released guidelines of the American College of Gastroenterology (ACG) have thoroughly reviewed on the genetic testing and management of hereditary gastrointestinal cancer syndromes. ${ }^{36}$ Peutz-Jeghers syndrome (PJS) is characterized by the development of benign hamartomatous polyps in the gastrointestinal tract, especially the small bowel, in association with muco-cutaneous pigmentation. Large (> 10 - $15 \mathrm{~mm}$ ) small bowel polyps are prone to complications such as acute gastrointestinal bleeding, intussusception or bowel obstruction, and also have a malignant potential. ${ }^{37}$ Small bowel surveillance allows for the detection of large polyps and further referral for endoscopic or surgical removal. The recent ACG guidelines suggest to start with SBCE at age 8 years; if polyps are present, repeat every 3 years; if no polyps are detected, SBCE should be repeated at age 18, then every 3 years, or earlier if symptoms occur. ${ }^{36}$ However, it is recognized that even large polyps may be missed by SBCE, especially if located in the proximal small bowel. Gupta et $\mathrm{al}^{38}$ followed a cohort of 19 patients with 41 polyps greater than $10 \mathrm{~mm}$, which were detected by either MRE or SBCE. Although SBCE was better for the identification of smaller polyps (6-10mm), it missed three large polyps (> 15 $\mathrm{mm}$ ) that were detected by MRE. Thus, these examinations may be considered complementary. In patients with familial adenomatous polyposis (FAP), there is no evidence to support the routine use of SBCE when the diagnosis is established, ${ }^{31,36}$ as standard endoscopy is superior for the detection of periampullary and duodenal polyps. ${ }^{39}$ There is also no current indication for the routine use of SBCE in patients with a diagnosis of Lynch syndrome. ${ }^{31,36}$ In a recent study of 200 asymptomatic patients with Lynch syndrome, ${ }^{40}$ the prevalence of small bowel neoplasia was $1.5 \%$, and all neoplastic lesions were located in the duodenum, easily accessible to conventional EGD. The risk of capsule retention may be increased in some patients with polyposis syndromes, such as FAP patients with intra-abdominal desmoid tumors or patients with PJS who underwent previous small bowel surgical resections; therefore, small bowel cross-sectional imaging and/or patency capsule should be performed if SBCE is being considered.

\section{Crohn's disease}

Suspected Crohn's disease. Ileocolonoscopy remains the first line examination in patients with suspected Crohn's disease (CD). However, SBCE may be considered, in the absence of obstructive symptoms or known stenosis, when ileocolonoscopy is non-diagnostic, when retrograde ileoscopy is not technically feasible, or when small bowel lesions proximal to the level reached by the colonoscope are suspected. ${ }^{41}$ In patients with suspected small bowel stenoses, SBCE should only be considered if functional patency of the small bowel is previously confirmed by small bowel cross-sectional imaging and/or the Agile ${ }^{\mathrm{TM}}$ patency capsule. ${ }^{42}$ SBCE has a high sensitivity for lesions consistent with small bowel $C D$, including mild lesions and those located in the proximal small bowel. ${ }^{43-45}$ In patients with suspected $C D$, it is possible to confidently exclude the diagnosis when no lesions are identified by $\mathrm{SBCE}^{46}$. However, the lesions which are typical of active small bowel CD, such as villous oedema or aphthous ulcerations (Fig. 3), are not diseasespecific, looking similar to other entities such as NSAIDs enteropathy, tuberculosis, Behçet's disease, ulcerative jejuno-ileitis, lymphoma, small bowel ischemia or radiation enteropathy. ${ }^{41}$ There are no validated diagnostic criteria for establishing the diagnosis of CD by SBCE. The Lewis Score (LS) and the Capsule Endoscopy Crohn's Disease Activity Index (CECDAI) have been validated as cumulative quantitative scores that measure the severity of inflammatory activity, and contribute to standardise reporting and increase interobserver agreement. ${ }^{47,48}$ A software application for the automatic calculation of the LS is available in the Rapid Reader $^{\circledR}$ workstation (Given Imaging, Yokneam, Israel). However, although these scoring systems can quantitatively describe the type, distribution and severity of mucosal lesions, they cannot be used independently as a diagnostic tool, as they grade inflammatory activity regardless of its etiology. Hence, careful patient selection remains essential to increase the specificity and the positive predictive value of SBCE findings. Direct assessment and biopsies may be important in patients in whom diagnoses such as infections or malignancy, which may mimic the clinical presentation of CD, have to be excluded. ${ }^{49}$ The International Conference on Capsule Endoscopy (ICCE $)^{31}$ recommended that patients with suspected CD are appropriate candidates for SBCE if presenting with typical symptoms such as

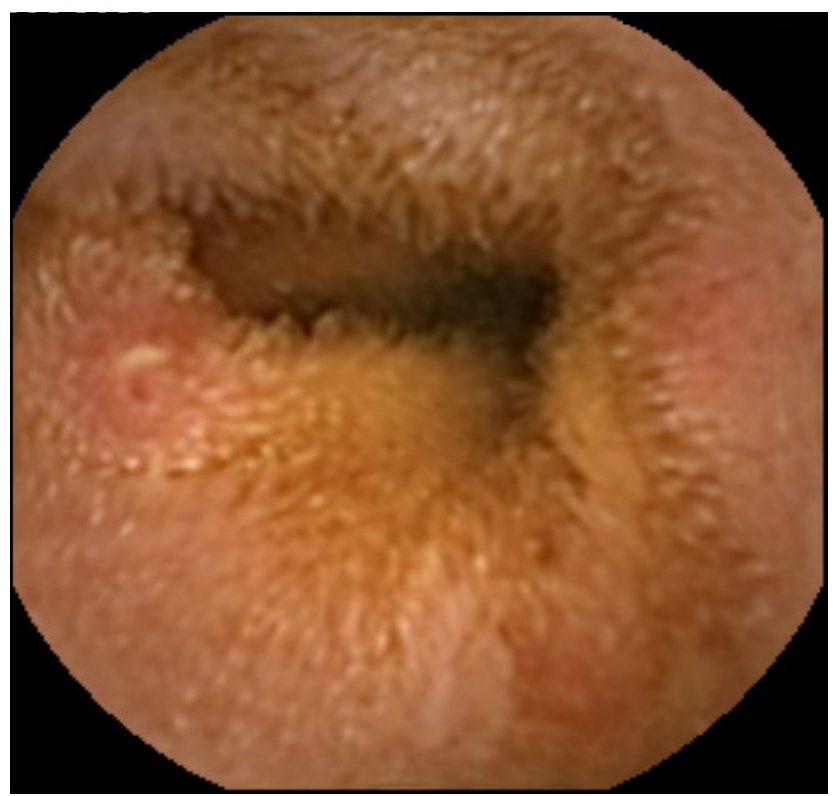

Figure 3 - Small bowel villous oedema and aphthous ulceration in a patient with Crohn's disease 
chronic abdominal pain, chronic diarrhoea, weight loss or growth failure, 'in addition' to extra-intestinal manifestations typical of IBD such as fever, arthritis/arthralgia, pyoderma gangrenosum, perianal disease and/or primary sclerosing cholangitis, raised serum and/or inflammatory markers, and/or abnormal small bowel imaging. In a retrospective study, SBCE detected significant inflammatory activity in $17.8 \%$ of patients who did not meet those ICCE criteria, in $57.9 \%$ of those fulfilling two criteria and in $77.8 \%$ when 3 or more criteria were present, and CD was confirmed during follow-up in $21.4 \%, 52.6 \%$ and $77.8 \%$ of these patients, respectively. ${ }^{50}$ SBCE may also be useful in patients with inflammatory bowel disease unclassified (IBDU), although a negative examination cannot definitely exclude a future diagnosis of $C D^{51}$ in this setting.

Known Crohn's disease. Assessment of extent and severity of disease activity.

In patients with known CD, irrespective of the findings at ileocolonoscopy, the small bowel should be investigated to evaluate disease extent and activity, ${ }^{52}$ as it may influence prognosis and therapeutic decisions. Cross sectional imaging with CTE or MRE generally takes precedence over SBCE, being able to identify strictures and to assess the transmural and extra-luminal nature of the disease and its anatomical distribution. In the absence of clinical or radiological evidence of stenoses, SBCE may be considered if additional findings are likely to result in a modification of clinical management. ${ }^{53}$ Although the risk of capsule retention is slightly increased in these patients, it can often be managed conservatively or retrieved by BAE. ${ }^{54}$ SBCE improves the detection of lesions in the proximal small bowel when compared to both CTE and MRE, detecting proximal lesions in up to $50 \%$ of patients with previously diagnosed ileal CD. ${ }^{55}$ Jejunal involvement has been recognized as an independent marker of severity in $\mathrm{CD}$, being associated with an increased risk of relapse, ${ }^{55}$ higher use of corticosteroids (HR 1.24; 95\% Cl: 1.02 - 1.50) and thiopurines (HR 1.26; $95 \% \mathrm{Cl}: 1.06-1.49)$, higher rates of strictureplasties (RR 2.52; 95\% Cl: 1.60 - 3.96), hospitalizations (RR 1.29; 95\% $\mathrm{Cl}: 1.14$ - 1.47), and longer hospitalization duration (RR, $1.30 ; 95 \% \mathrm{Cl}, 1.25-1.34) .{ }^{56}$ Recently, it was reported that treatment with thiopurines and/or biologics was started more often in patients with proximal small bowel lesions detected by SBCE $[13 / 33(39 \%)$ vs $1 / 17(6 \%), p=0.011$, relative risk (RR) 6.5], particularly when severe $(6 \%, 36 \%$ and $45 \%$ of patients with non-significant, mild and moderate-to-severe inflammation, respectively). ${ }^{53}$

\section{Patients with suspected obscure GI bleeding or ongoing symptoms.}

SBCE has been used to investigate CD patients in the setting of unexplained iron-deficiency anemia or visible OGIB, ${ }^{41}$ or to investigate patients with ongoing symptoms suggestive of active disease. ${ }^{57}$ Mehdizadeh et al ${ }^{58}$ reported normal SBCE findings in $48 \%$ of symptomatic patients with small bowel $C D$, guiding the investigation to alternative diagnoses such as concurrent irritable bowel syndrome, bile salt malabsorption or bacterial overgrowth.

\section{Assessment of mucosal healing}

Small bowel mucosal healing is an important endpoint of treatment efficacy. The use of validated quantitative scales with good inter-observer agreement such as the Lewis score ${ }^{59}$ or the CECDAI, ${ }^{47}$ with adoption of a standardized definition of mucosal healing, seems particularly relevant in this setting. SBCE enables a longitudinal assessment of the course of the disease and its response to medical therapy. ${ }^{60,61}$ However, there is currently insufficient evidence to support its use for this indication in routine clinical practice.

\section{Postoperative disease recurrence}

Pons Beltran et $a^{62}$ evaluated $24 C D$ patients for postoperative recurrence. SBCE detected CD neo-terminal ileal disease recurrence in $62 \%$ of patients, whereas ileocolonoscopy detected inflammatory lesions within the neo-terminal ileum in $25 \%$ of patients. Conversely, in another study, the sensitivity of SBCE for endoscopic recurrence in the neo-terminal ileum was inferior to that of ileocolonoscopy, although proximal lesions were detected in more than two thirds of patients. ${ }^{63}$ Although SBCE has been shown to detect proximal small bowel lesions in patients with $C D$ early after surgery, the clinical significance of these findings and how they may impact on patient management is currently unknown. Thus, SBCE should currently be considered only when ileocolonoscopy is unsuccessful for the assessment of postoperative recurrence.

\section{Celiac disease}

Celiac disease is one of the most prevalent enteropathies in western countries, affecting $0.2-2 \%$ of the population. ${ }^{64}$ The first step for diagnosing celiac disease is usually a serological test, using the immunoglobulin $\mathrm{A}(\lg \mathrm{A})$ antihuman tissue transglutaminase (t-TG) and $\operatorname{IgA}$ endomysial antibody immunofluorescence (EMA). Although serological testing is highly sensitive and specific, EGD with biopsies of the duodenum remains the standard for the diagnosis of celiac disease. Four typical endoscopic markers of celiac disease have been described: loss or reduction in duodenal Kerkring's folds, mosaic or micronodular mucosal pattern, scalloped configuration of duodenal folds and visibility of the underlying blood vessels. ${ }^{65}$ The reported specificity for these classical endoscopic markers ranges from $87 \%$ to $100 \%$, while the sensitivity may range from $50 \%$ to $94 \% .65,66$ Therefore, small bowel histopathology remains essential for the diagnosis, typically showing villous atrophy, increased intraepithelial lymphocytes and hyperplastic crypts. ${ }^{65}$ However, adequate and properly oriented tissue samples are sometimes difficult to obtain, and patchy mucosal lesions may be missed, precluding a definite histopathologic diagnosis. A few studies have reported a sensitivity of $67 \%-93 \%$, specificity of $63.6 \%-100 \%$, positive predictive value (PPV) of $96.5 \%-100 \%$ and negative predictive value 
(NPV) of $60 \%$ - $89 \%$ for the diagnosis of celiac disease with SBCE. ${ }^{67,68}$ Barret et al ${ }^{69}$ reported that the concordance of SBCE with histology for villous atrophy was better than that of upper $\mathrm{Gl}$ endoscopy (kappa coefficient $=0.45$ vs $0.24, p<0.001)$. In a meta-analysis, El-Matary et $\mathrm{al}^{70}$ reported a pooled sensitivity and specificity of SBCE for the diagnosis of celiac disease of $83 \%(95 \% \mathrm{Cl}: 71 \%$ - 90\%) and 98\% (95\% Cl: $88 \%$ - 99.6\%), respectively, while another recent meta-analysis ${ }^{71}$ reported a pooled sensitivity of $89 \%(95 \% \mathrm{Cl}: 82 \%-94 \%)$ and specificity of $95 \%(95 \% \mathrm{Cl}: 89-98 \%)$. In view of these results, it remains a topic of discussion whether SBCE could be a valid diagnostic examination in selected cases, such as in patients unable or unwilling to undergo conventional upper GI endoscopy, or those with positive serologic tests and negative duodenal biopsies. In patients with an established diagnosis of celiac disease, SBCE has the main advantage of being a non-invasive technique capable of visualizing the entire small bowel, establishing the extent of small bowel involvement and enabling the diagnosis of complications of long-standing celiac disease, such as small bowel adenocarcinoma, enteropathy associated T-cell lymphoma (EATL) and ulcerative jejuno-ileitis, which are often located beyond the site reached by EGD, and may also be missed by other small bowel imaging modalities. Petroniene et $\mathrm{al}^{65}$ reported that the extent of small bowel involvement may be related to the severity of symptoms in celiac disease. Poor nutritional status and low serum albumin levels have also been associated with extensive small bowel damage. ${ }^{72}$ Extensive ulcerative jejuno-ileitis may be observed in more than half of patients with refractory celiac disease (RCD) type II (54\%) and it is associated with a high risk of developing EATL. ${ }^{69}$ The risk of capsule

\section{REFERENCES}

1. Triester SL, Leighton JA, Leontiadis GI, Fleischer DE, Hara AK, Heigh $\mathrm{RI}$, et al. A meta-analysis of the yield of capsule endoscopy compared to other diagnostic modalities in patients with obscure gastrointestinal bleeding. Am J Gastroenterol. 2005;100:2407-18.

2. Pennazio M, Spada C, Eliakim R, Keuchel M, May A, Mulder CJ, et al. Small-bowel capsule endoscopy and device-assisted enteroscopy for diagnosis and treatment of small-bowel disorders: European Society of Gastrointestinal Endoscopy (ESGE) Clinical Guideline. Endoscopy. 2015;47:352-86.

3. Ell C, May A. Mid-gastrointestinal bleeding: capsule endoscopy and push-and-pull enteroscopy give rise to a new medical term. Endoscopy. 2006;38:73-5

4. Ladas SD, Triantafyllou K, Spada C, Riccioni ME, Rey JF, Niv Y, et al. European Society of Gastrointestinal Endoscopy (ESGE): recommendations (2009) on clinical use of video capsule endoscopy to investigate small-bowel, esophageal and colonic diseases. Endoscopy. 2010;42:220-7

5. Liao Z, Gao R, Xu C, Li ZS. Indications and detection, completion, and retention rates of small-bowel capsule endoscopy: a systematic review. Gastrointest Endosc. 2010;71:280-6.

6. Marmo R, Rotondano G, Piscopo R, Bianco MA, Siani A, Catalano $\mathrm{O}$, et al. Capsule endoscopy versus enteroclysis in the detection of small-bowel involvement in Crohn's disease: a prospective trial. Clin Gastroenterol Hepatol. 2005;3:772-6.

7. Pasha SF, Leighton JA, Das A, Harrison ME, Decker GA, Fleischer $\mathrm{DE}$, et al. Double-balloon enteroscopy and capsule endoscopy have comparable diagnostic yield in small-bowel disease: a meta-analysis. Clin Gastroenterol Hepatol. 2008;6:671-6.

8. Sethi S, Cohen J, Thaker AM, Garud S, Sawhney MS, Chuttani R, et al. retention in patients with suspected complications of longstanding celiac disease advices preliminary radiological imaging of the small bowel or patency capsule in order to rule out stricturing disease..$^{42,69}$ In a series of 47 high risk celiac patients with persistent unexplained abdominal pain, weight loss, history of small bowel neoplasia, long-standing celiac disease, positive faecal occult blood test or iron deficiency anaemia unresponsive to iron supplementation, SBCE detected significant lesions in approximately $60 \%$ of cases. $^{73}$ These data support the use of SBCE in patients with long-standing complicated celiac disease, who present with alarm symptoms or do not respond to gluten-free diet.

\section{CONCLUSIONS}

SBCE revolutionized the diagnostic approach of small bowel diseases, and its relative positioning within the management algorithms of patients with OGIB, suspected small bowel tumors, CD and coeliac disease has been rapidly evolving in the past few years. In the future, new features such as the ability to obtain new image reconstructions, sample luminal fluids and mucosal tissue or the possibility to remotely control the capsule and performing therapeutic procedures are likely to further expand the field of capsule technology, ${ }^{74,75}$ providing new high-tech management opportunities with the compromise of less invasiveness and convenience for patients.

\section{CONFLICTS OF INTEREST}

The authors state no conflict of interests and have received no payment to perform this work.

\section{FUNDING SOURCES}

No subsidies or grants contributed to this work.

Prior capsule endoscopy improves the diagnostic and therapeutic yield of single-balloon enteroscopy. Dig Dis Sci. 2014;59:2497-502.

9. Koulaouzidis A, Rondonotti E, Giannakou A, Plevris JN. Diagnostic yield of small-bowel capsule endoscopy in patients with iron-deficiency anemia: a systematic review. Gastrointest Endosc. 2012;76:983-92.

10. Pennazio M, Santucci R, Rondonotti E, Abbiati C, Beccari G, Rossini FP, et al. Outcome of patients with obscure gastrointestinal bleeding after capsule endoscopy: report of 100 consecutive cases. Gastroenterology. 2004;126:643-53.

11. Bresci G, Parisi G, Bertoni M, Tumino E, Capria A. The role of video capsule endoscopy for evaluating obscure gastrointestinal bleeding: usefulness of early use. J Gastroenterol. 2005;40:256-9.

12. Lecleire S, Iwanicki-Caron I, Di-Fiore A, Elie C, Alhameedi R, Ramirez $S$, et al. Yield and impact of emergency capsule enteroscopy in severe obscure-overt gastrointestinal bleeding. Endoscopy. 2012;44:337-42.

13. Singh A, Marshall C, Chaudhuri B, Okoli C, Foley A, Person SD, et al. Timing of video capsule endoscopy relative to overt obscure $\mathrm{Gl}$ bleeding: implications from a retrospective study. Gastrointest Endosc. 2013;77:761-6

14. Leung WK, Ho SS, Suen BY, Lai LH, Yu S, Ng EK, et al. Capsule endoscopy or angiography in patients with acute overt obscure gastrointestinal bleeding: a prospective randomized study with longterm follow-up. Am J Gastroenterol. 2012;107:1370-6.

15. Albert JG, Nachtigall F, Wiedbrauck F, Dollinger MM, Gittinger FS, Hollerbach S, et al. Minimizing procedural cost in diagnosing small bowel bleeding: comparison of a strategy based on initial capsule endoscopy versus initial double-balloon enteroscopy. Eur J Gastroenterol Hepatol. 2010;22:679-88.

16. Hindryckx P, Botelberge T, De Vos M, De Looze D. Clinical impact of 
capsule endoscopy on further strategy and long-term clinical outcome in patients with obscure bleeding. Gastrointest Endosc. 2008;68:98-104.

17. Endo H, Matsuhashi N, Inamori M, Akimoto K, Ohya T, Yanagawa T, et al. Rebleeding rate after interventional therapy directed by capsule endoscopy in patients with obscure gastrointestinal bleeding. BMC Gastroenterol. 2008;8:12.

18. Rahmi G, Samaha E, Vahedi K, Delvaux M, Gay G, Lamouliatte H, et al. Long-term follow-up of patients undergoing capsule and double-balloon enteroscopy for identification and treatment of small-bowel vascular lesions: a prospective, multicenter study. Endoscopy. 2014;46:591-7.

19. Lai LH, Wong GL, Chow DK, Lau JY, Sung JJ, Leung WK. Longterm follow-up of patients with obscure gastrointestinal bleeding after negative capsule endoscopy. Am J Gastroenterol. 2006;101:1224-8

20. Macdonald J, Porter V, McNamara D. Negative capsule endoscopy in patients with obscure $\mathrm{Gl}$ bleeding predicts low rebleeding rates. Gastrointest Endosc. 2008;68:1122-7.

21. Curdia Goncalves T, Dias de Castro F, Moreira MJ, Rosa B, Cotter J. Small bowel capsule endoscopy in obscure gastrointestinal bleeding: normalcy is not reassuring. Eur J Gastroenterol Hepatol. 2014;26:92732

22. Matsumura T, Arai M, Saito K, Okimoto K, Saito M, Minemura S, et al. Predictive factor of re-bleeding after negative capsule endoscopy for obscure gastrointestinal bleeding: over 1-year follow-up study. Dig Endosc. 2014;26:650-8

23. Appleyard M, Fireman Z, Glukhovsky A, Jacob $H$, Shreiver $R$, Kadirkamanathan $\mathrm{S}$, et al. A randomized trial comparing wireless capsule endoscopy with push enteroscopy for the detection of smallbowel lesions. Gastroenterology. 2000;119:1431-8.

24. Saurin JC, Delvaux M, Gaudin JL, Fassler I, Villarejo J, Vahedi K, et al. Diagnostic value of endoscopic capsule in patients with obscure digestive bleeding: blinded comparison with video push-enteroscopy. Endoscopy. 2003;35:576-84.

25. Imagawa H, Oka S, Tanaka S, Noda I, Higashiyama M, Sanomura Y, et al. Improved detectability of small-bowel lesions via capsule endoscopy with computed virtual chromoendoscopy: a pilot study. Scand J Gastroenterol. 2011;46:1133-7.

26. Cotter J, Magalhaes J, de Castro FD, Barbosa M, Carvalho PB, Leite S, et al. Virtual chromoendoscopy in small bowel capsule endoscopy: New light or a cast of shadow? World J Gastrointest Endosc. 2014;6:359-65.

27. Islam RS, Leighton JA, Pasha SF. Evaluation and management of smallbowel tumors in the era of deep enteroscopy. Gastrointest Endosc. 2014;79:732-40.

28. Cheung DY, Lee IS, Chang DK, Kim JO, Cheon JH, Jang BI, et al. Capsule endoscopy in small bowel tumors: a multicenter Korean study. J Gastroenterol Hepatol. 2010;25: 1079-86.

29. Rondonotti E, Pennazio M, Toth E, Menchen P, Riccioni ME, De Palma $\mathrm{GD}$, et al. Small-bowel neoplasms in patients undergoing video capsule endoscopy: a multicenter European study. Endoscopy. 2008;40:488-95.

30. Chong AK, Chin BW, Meredith CG. Clinically significant small-bowe pathology identified by double-balloon enteroscopy but missed by capsule endoscopy. Gastrointest Endosc. 2006;64:445-9.

31. Mergener K, Ponchon T, Gralnek I, Pennazio M, Gay G, Selby W, et al. Literature review and recommendations for clinical application of smallbowel capsule endoscopy, based on a panel discussion by international experts. Consensus statements for small-bowel capsule endoscopy, 2006/2007. Endoscopy. 2007;39:895-909.

32. Lewis BS, Eisen GM, Friedman S. A pooled analysis to evaluate results of capsule endoscopy trials. Endoscopy. 2005;37:960-5.

33. Honda W, Ohmiya N, Hirooka Y, Nakamura M, Miyahara R, Ohno E, et al. Enteroscopic and radiologic diagnoses, treatment, and prognoses of small-bowel tumors. Gastrointest Endosc. 2012;76:344-54.

34. Li X, Chen H, Dai J, Gao Y, Ge Z. Predictive role of capsule endoscopy on the insertion route of double-balloon enteroscopy. Endoscopy. 2009;41:762-6.

35. Girelli CM, Porta P, Colombo E, Lesinigo E, Bernasconi G. Development of a novel index to discriminate bulge from mass on small-bowel capsule endoscopy. Gastrointest Endosc. 2011;74:1067-74

36. Syngal S, Brand RE, Church JM, Giardiello FM, Hampel HL, Burt RW. ACG clinical guideline: Genetic testing and management of hereditary gastrointestinal cancer syndromes. Am J Gastroenterol. 2015;110:22362

37. van Lier MG, Wagner A, Mathus-Vliegen EM, Kuipers EJ, Steyerberg EW, van Leerdam ME. High cancer risk in Peutz-Jeghers syndrome: a systematic review and surveillance recommendations. Am J Gastroenterol. 2010;105:1258-64.

38. Gupta A, Postgate AJ, Burling D, Ilangovan R, Marshall M, Phillips RK, et al. A prospective study of MR enterography versus capsule endoscopy for the surveillance of adult patients with Peutz-Jeghers syndrome. AJR Am J Roentgenol. 2010;195:108-16

39. Koulaouzidis A, Rondonotti E, Karargyris A. Small-bowel capsule endoscopy: a ten-point contemporary review. World J Gastroenterol. 2013;19:3726-46.

40. Haanstra JF, Al-Toma A, Dekker E, Vanhoutvin SA, Nagengast FM Mathus-Vliegen EM, et al. Prevalence of small-bowel neoplasia in Lynch syndrome assessed by video capsule endoscopy. Gut. 2015;64:157883.

41. Annese V, Daperno M, Rutter MD, Amiot A, Bossuyt P, East J, et al European evidence based consensus for endoscopy in inflammatory bowel disease. J Crohns Colitis. 2013;7:982-1018.

42. Herrerias JM, Leighton JA, Costamagna G, Infantolino A, Eliakim $\mathrm{R}$, Fischer $\mathrm{D}$, et al. Agile patency system eliminates risk of capsule retention in patients with known intestinal strictures who undergo capsule endoscopy. Gastrointest Endosc. 2008;67:902-9.

43. Jensen MD, Nathan T, Rafaelsen SR, Kjeldsen J. Diagnostic accuracy of capsule endoscopy for small bowel Crohn's disease is superior to that of MR enterography or CT enterography. Clin Gastroenterol Hepatol. 2011;9:124-9.

44. Dionisio PM, Gurudu SR, Leighton JA, Leontiadis GI, Fleischer DE, Hara AK, et al. Capsule endoscopy has a significantly higher diagnostic yield in patients with suspected and established small-bowel Crohn's disease: a meta-analysis. Am J Gastroenterol. 2010;105:1240-8.

45. Leighton JA, Gralnek IM, Cohen SA, Toth E, Cave DR, Wolf DC, et al. Capsule endoscopy is superior to small-bowel follow-through and equivalent to ileocolonoscopy in suspected Crohn's disease. Clin Gastroenterol Hepatol. 2014;12:609-15.

46. Tukey M, Pleskow D, Legnani P, Cheifetz AS, Moss AC. The utility of capsule endoscopy in patients with suspected Crohn's disease. Am J Gastroenterol. 2009;104:2734-9.

47. Niv Y, Ilani S, Levi Z, Hershkowitz M, Niv E, Fireman Z, et al. Validation of the Capsule Endoscopy Crohn's Disease Activity Index (CECDAI or Niv score): a multicenter prospective study. Endoscopy. 2012;44:21-6.

48. Cotter J, Dias de Castro F, Magalhaes J, Moreira MJ, Rosa B. Validation of the Lewis score for the evaluation of small-bowel Crohn's disease activity. Endoscopy. 2015;47:330-5.

49. Schulz C, Monkemuller K, Salheiser M, Bellutti M, Schutte $K$ Malfertheiner P. Double-balloon enteroscopy in the diagnosis of suspected isolated Crohn's disease of the small bowel. Dig Endosc. 2014;26:236-42

50. Rosa B, Moreira MJ, Rebelo A, Cotter J. Lewis Score: a useful clinical tool for patients with suspected Crohn's Disease submitted to capsule endoscopy. J Crohns Colitis. 2012;6:692-7.

51. Henriksen M, Jahnsen J, Lygren I, Sauar J, Schulz T, Stray N, et al. Change of diagnosis during the first five years after onset of inflammatory bowel disease: results of a prospective follow-up study (the IBSEN Study). Scand J Gastroenterol. 2006;41:1037-43.

52. Van Assche $G$, Dignass A, Panes $J$, Beaugerie $L$, Karagiannis $J$, Allez $\mathrm{M}$, et al. The second European evidence-based Consensus on the diagnosis and management of Crohn's disease: Definitions and diagnosis. J Crohns Colitis. 2010;4:7-27

53. Cotter J, Dias de Castro F, Moreira MJ, Rosa B. Tailoring Crohn's disease treatment: The impact of small bowel capsule endoscopy. J Crohns Colitis. 2014;8:1610-5.

54. Despott EJ, Fraser C. Small bowel endoscopy in inflammatory bowe disease. Best Pract Res Clin Gastroenterol. 2012;26:279-91.

55. Flamant M, Trang C, Maillard O, Sacher-Huvelin S, Le Rhun M, Galmiche $\mathrm{JP}$, et al. The prevalence and outcome of jejunal lesions visualized by small bowel capsule endoscopy in Crohn's disease. Inflamm Bowel Dis. 2013;19:1390-6.

56. Park SK, Yang SK, Park SH, Kim JW, Yang DH, Jung KW, et al. Long term prognosis of the jejunal involvement of Crohn's disease. J Clin Gastroenterol. 2013:47:400-8.

57. Kopylov U, Nemeth A, Koulaouzidis A, Makins R, Wild G, Afif W, et al. Small bowel capsule endoscopy in the management of established Crohn's disease: clinical impact, safety, and correlation with inflammatory biomarkers. Inflamm Bowel Dis. 2015;21:93-100.

58. Mehdizadeh S, Chen GC, Barkodar L, Enayati PJ, Pirouz S, Yadegar $M$, et al. Capsule endoscopy in patients with Crohn's disease: diagnostic yield and safety. Gastrointest Endosc. 2010;71:121-7.

59. Gralnek IM, Defranchis R, Seidman E, Leighton JA, Legnani P, Lewis BS. Development of a capsule endoscopy scoring index for small bowel mucosal inflammatory change. Aliment Pharmacol Ther. 2008;27:14654. 
60. Niv E, Fishman S, Kachman H, Arnon R, Dotan I. Sequential capsule endoscopy of the small bowel for follow-up of patients with known Crohn's disease. J Crohns Colitis. 2014;8:1616-23.

61. Hall B, Holleran G, Chin JL, Smith S, Ryan B, Mahmud N, et al. A prospective 52 week mucosal healing assessment of small bowel Crohn's disease as detected by capsule endoscopy. J Crohns Colitis. 2014;8:1601-9.

62. Pons Beltran V, Nos P, Bastida G, Beltran B, Arguello L, Aguas M, et al. Evaluation of postsurgical recurrence in Crohn's disease: a new indication for capsule endoscopy? Gastrointest Endosc. 2007;66:53340.

63. Bourreille A, Jarry M, D'Halluin PN, Ben-Soussan E, Maunoury V, Bulois $P$, et al. Wireless capsule endoscopy versus ileocolonoscopy for the diagnosis of postoperative recurrence of Crohn's disease: a prospective study. Gut. 2006;55:978-83.

64. Ludvigsson JF, Rubio-Tapia A, van Dyke CT, Melton LJ 3rd, Zinsmeister AR, Lahr BD, et al. Increasing incidence of celiac disease in a North American population. Am J Gastroenterol. 2013;108:818-24.

65. Petroniene R, Dubcenco E, Baker JP, Warren RE, Streutker CJ, Gardiner $\mathrm{GW}$, et al. Given capsule endoscopy in celiac disease. Gastrointest Endosc Clin N Am. 2004;14:115-27.

66. Olds G, McLoughlin R, O'Morian C, Sivak MV Jr. Celiac disease for the endoscopist. Gastrointest Endosc. 2002;56:407-15.

67. Maiden L, Elliott T, McLaughlin SD, Ciclitira P. A blinded pilot comparison of capsule endoscopy and small bowel histology in unresponsive celiac disease. Dig Dis Sci. 2009;54:1280-3.
68. Lidums I, Cummins AG, Teo E. The role of capsule endoscopy in suspected celiac disease patients with positive celiac serology. Dig Dis Sci. 2011;56:499-505.

69. Barret M, Malamut G, Rahmi G, Samaha E, Edery J, Verkarre V, et al. Diagnostic yield of capsule endoscopy in refractory celiac disease. Am J Gastroenterol. 2012;107:1546-53.

70. El-Matary W, Huynh H, Vandermeer B. Diagnostic characteristics of given video capsule endoscopy in diagnosis of celiac disease: a metaanalysis. J Laparoendosc Adv Surg Tech A. 2009;19:815-20.

71. Rokkas T, Niv Y. The role of video capsule endoscopy in the diagnosis of celiac disease: a meta-analysis. Eur J Gastroenterol Hepatol. 2012;24:303-8

72. Rubio-Tapia A, Kelly DG, Lahr BD, Dogan A, Wu TT, Murray JA Clinical staging and survival in refractory celiac disease: a single center experience. Gastroenterology. 2009;136:99-107.

73. Culliford A, Daly J, Diamond B, Rubin M, Green PH. The value of wireless capsule endoscopy in patients with complicated celiac disease. Gastrointest Endosc. 2005;62:55-61.

74. Koulaouzidis A, Karargyris A, Rondonotti E, Noble CL, Douglas S, Alexandridis E, et al. Three-dimensional representation software as image enhancement tool in small-bowel capsule endoscopy: a feasibility study. Dig Liver Dis. 2013;45:909-14

75. Denzer UW, Rosch T, Hoytat B, Abdel-Hamid M, Hebuterne $X$ Vanbiervielt $G$, et al. Magnetically guided capsule versus conventional gastroscopy for upper abdominal complaints: a prospective blinded study. J Clin Gastroenterol. 2015;49:101-7. 
Bruno ROSA, José COTTER

\section{Current Clinical Indications for Small Bowel Capsule Endoscopy}

Acta Med Port 2015:28:632-639

Publicado pela Acta Médica Portuguesa, a Revista Científica da Ordem dos Médicos

Av. Almirante Gago Coutinho, 151

1749-084 Lisboa, Portugal.

Tel: +351218428 215

E-mail: submissao@actamedicaportuguesa.com

www.actamedicaportuguesa.com

ISSN:0870-399X | e-ISSN: 1646-0758

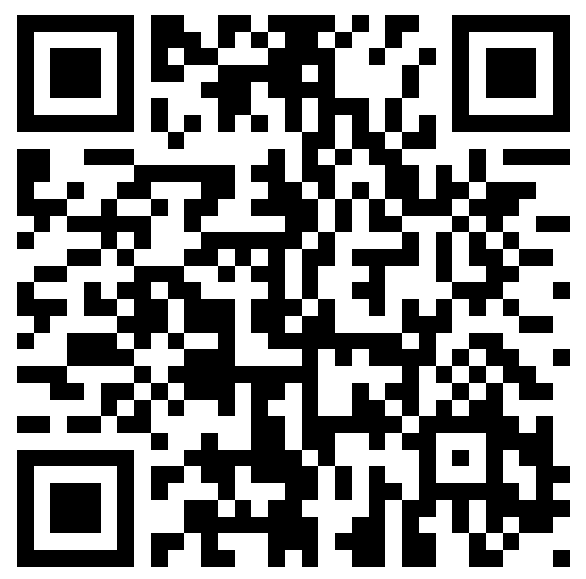

